Article

\title{
Study of Extraction and Enzymatic Properties of Cell-Envelope Proteinases from a Novel Wild Lactobacillus plantarum LP69
}

\author{
He Chen ${ }^{1}$, Jie Huang ${ }^{1, *(\mathbb{D})}$, Binyun Cao ${ }^{2}$, Li Chen ${ }^{3, *(\mathbb{D}}$, Na Song ${ }^{1}$ and Ni Lei ${ }^{1}$ \\ 1 School of Food and Biological Engineering, Shaanxi University of Science and Technology, \\ Xi'an 710021, China; chenhe419@gmail.com (H.C.); lhm542527328@163.com (N.S.); \\ lily469569@163.com (N.L.) \\ 2 College of Animal Science and Technology, Northwest A\&F University, Yangling 712100, China; \\ sombre-sky@163.com \\ 3 College of Food Engineering and Nutritional Science, Shaanxi Normal University, Xi'an 710119, China \\ * Correspondence: huangjie9319@gmail.com (J.H.); chenlisp@snnu.edu.cn (L.C.); Tel.: +86-183-9211-2739 \\ (J.H.); +86-029-85310517 (L.C.); Fax: +86-029-85310517 (L.C.)
}

Received: 17 July 2018; Accepted: 7 August 2018; Published: 8 August 2018

\begin{abstract}
Lactobacilli cell-envelope proteinases (CEPs) have been widely used in the development of new streams of blockbuster nutraceuticals because of numerous biopharmaceutical potentials; thus, the development of viable methods for CEP extraction and the improvement of extraction efficiency will promote their full-scale application. In this study, CEP from a novel wild Lactobacillus plantarum LP69 was released from cells by incubating in calcium-free buffer. The extraction conditions of CEP were optimized by response surface methodology with the enzyme activity and specific activity as the detective marker. The optimal extraction conditions were: time of $80 \mathrm{~min}$, temperature of $39{ }^{\circ} \mathrm{C}$ and buffer $\mathrm{pH}$ of 6.5. Under these conditions, enzyme activity and specific activity were $(23.94 \pm 0.86) \mathrm{U} / \mathrm{mL}$ and $(1.37 \pm 0.03) \mathrm{U} / \mathrm{mg}$, respectively, which were well matched with the predicted values $(22.12 \mathrm{U} / \mathrm{mL}$ and $1.36 \mathrm{U} / \mathrm{mg})$. Optimal activity of the crude CEP occurred at $\mathrm{pH} 8.0$ and $40{ }^{\circ} \mathrm{C}$. It is a metallopeptidase, activated by $\mathrm{Ca}^{2+}$, inhibited by $\mathrm{Zn}^{2+}$ and ethylene-diamine-tetra-acetic acid, and a serine proteinase which is inhibited by phenylmethylsulfonyl fluoride. Kinetic studies showed that CEP from LP69 could hydrolyze whey protein, lactoglobulin and casein. Our study improves the extraction efficiency of CEPs from LP69, providing the reference for their industrial development.
\end{abstract}

Keywords: Lactobacillus plantarum LP69; cell-envelope proteinases; extraction conditions; response surface methodology; enzymatic properties

\section{Introduction}

Lactic acid bacteria (LAB) have proteolytic systems which consist of a cell-envelope proteinase (CEP) and a host of intracellular peptidases such as endopeptidases, aminopeptidases, tripeptidases and dipeptidases [1]. The proteolytic system can hydrolyze proteins and subsequently release different sizes of peptides and some free amino acids to meet the needs of bacterial growth. The peptides produced by hydrolysis exhibit various biological activities, such as antioxidative, antimicrobial, antihypertensive, immunomodulatory and cytomodulatory effects [2]. The CEP, anchored at the LAB surface, is an important enzyme in the proteolytic system, since it is responsible for the initial stage in the hydrolysis of milk proteins which is beneficial to the development of texture and sensory characteristics of fermented dairy products. Moreover, CEPs may also cause the release of bioactive peptides from food proteins which can contribute to health improvement beyond basic nutrition [3]. 
CEPs have many biotechnological potentials. The development of efficient and commercially feasible methods for CEP extraction and the optimization of the extraction conditions, including $\mathrm{pH}$, conductivity and temperature are therefore essential. Several methods have been confirmed for releasing CEPs from lactobacilli [4-6]. The most commonly used approach of extracting CEPs from lactobacilli is by washing the cells with a calcium-free buffer [4,7]. However, this method could not release CEP from some lactobacilli species [8-10]. Other methods have also been used to extract cell-surface-associated proteins, such as the use of muramidases, lithium chloride, guanidine hydrochloride, glycine, and urea. A study found that the presence of urea led to many cell surface proteins released from Lactobacillus rhamnosus [6]. Bhowmik et al. [11] also observed that guanidine hydrochloride solution was the most effective extraction agent on Lactobacillus acidophilus, since it could release abundant cell surface proteins. The proteinases from Lactobacillus delbrueckii subsp. bulgaricus CNRZ 397 were released by the use of lysozyme/mutanolysin treatment with cold temperature shock [12]. Agyei [13] found that some extraction methods did not extract CEPs from certain lactobacillis, which depend on the differences in the localization of CEPs on the bacterial cell-envelope. Therefore, the method for the release of CEP is dependent on the species and/or strain, and no single method is suitable for all lactobacilli.

In the past few decades, the proteolytic systems of Lactococcus have been widely studied, especially regarding biochemical and genetic aspects. Unlike the lactococcal proteolytic system, limited information is available on the proteolytic activity of lactobacilli $[3,14]$. Among the lactobacilli, the proteinase system of Lactobacillus casei has been extensively studied [4,15]. Properties of partly purified Lactobacillus CEP have been reported for L. delbrueckii subsp. bulgaricus [16], Lactobacillus sanfrancisco CB1 [17], Lactobacillus helveticus [14] and L. delbrueckii subsp. lactis [3]. A previous study identified the sub-cellular location of CEPs from L. delbrueckii subsp. lactis 313 and compared that the influence of different extraction methods on enzyme activity of CEPs from L. delbrueckii subsp. lactis 313 [13]. Besides, another study found that the CEPs from L. helveticus CRL 1062 was existed in the cell membrane fraction and obtained the maximum activity at $\mathrm{pH}$ 6.5-7.0 and $42{ }^{\circ} \mathrm{C}$ [14]. However, to date, the proteinase system of Lactobacillus plantarum has been less described.

L. plantarum is a commercially typical probiotic, which contributes to flavor development during the fermentation process. It could be helpful for improving the digestion of dairy products by lactose-intolerant patients [18]. However, relatively little is known about the biochemical and research data of L. plantarum LP69 in the dairy industry, and L. plantarum LP69 remains an understudied species. In previous studies, we have found that the goat milk fermented by L. plantarum LP69 exhibited strong ACE-inhibitory activity and antioxidant activity $[19,20]$. We further studied the proteolytic system of CEP from LP69 and found that hydrolysates of goat milk catalyzed by CEP have strong ACE-inhibitory activity and antioxidant activity, which showed that CEPs of L. plantarum could hydrolyze goat milk and subsequently release bioactive peptides [18]. The scope of technological and industrial applications of CEPs from LP69 is therefore expansible, but these prospects largely depend on the extraction efficiency of CEP. Thus, the purpose of this study was to optimize the extraction conditions of CEP from L. Plantarum LP69 by response surface methodology (RSM) and further study the enzymatic properties of the crude CEP from LP69.

\section{Results}

\subsection{Optimization of Extraction Conditions of CEP by RSM}

\subsubsection{Box-Behnken Design and Response Surface Method}

The enzyme activity $(\mathrm{U} / \mathrm{mL})$ and specific activity $(\mathrm{U} / \mathrm{mg})$ is represented by $Y_{1}$ and $Y_{2}$, respectively. The results of the Box-Behnken design for extracting conditions of CEP from L. plantarum LP69 are shown in Table 1. Response results of enzyme activity and specific activity are shown in Table 2. 
Table 1. Experimental design used in RSM studies by using three independent variables with three central points, showing observed enzyme activity $\left(Y_{1}, \mathrm{U} / \mathrm{mL}\right)$ and specific activity $\left(Y_{2}, \mathrm{U} / \mathrm{mg}\right)$. Time $\left(\min , \mathrm{X}_{1}\right)$, temperature $\left({ }^{\circ} \mathrm{C}, \mathrm{X}_{2}\right)$ and $\mathrm{pH}\left(\mathrm{X}_{3}\right)$ were chosen as the three independent variables.

\begin{tabular}{|c|c|c|c|c|c|}
\hline \multirow[b]{2}{*}{ Runs } & \multicolumn{3}{|c|}{ Variables } & \multirow{2}{*}{$\begin{array}{c}\text { Enzyme } \\
\text { Activity } \\
\left(Y_{1}, \mathrm{U} / \mathrm{mL}\right)\end{array}$} & \multirow{2}{*}{$\begin{array}{c}\text { Specific } \\
\text { Activity } \\
\left(Y_{2}, \mathrm{U} / \mathrm{mg}\right)\end{array}$} \\
\hline & $\begin{array}{c}\text { Time } \\
\left(\min , X_{1}\right)\end{array}$ & $\begin{array}{l}\text { Temperature } \\
\quad\left({ }^{\circ} \mathrm{C}, \mathrm{X}_{2}\right)\end{array}$ & $\begin{array}{l}\mathrm{pH} \\
\left(\mathrm{X}_{3}\right)\end{array}$ & & \\
\hline 1 & $1(90)$ & $0(39)$ & $1(7.0)$ & $17.6 \pm 0.52$ & $1.31 \pm 0.02$ \\
\hline 2 & $0(75)$ & 0 & $0(6.5)$ & $20.64 \pm 0.73$ & $1.35 \pm 0.04$ \\
\hline 3 & 1 & $-1(37)$ & 0 & $15.84 \pm 0.59$ & $1.22 \pm 0.06$ \\
\hline 4 & $-1(60)$ & 0 & 1 & $11.75 \pm 0.66$ & $1.31 \pm 0.02$ \\
\hline 5 & -1 & 0 & $-1(6.0)$ & $14.34 \pm 0.71$ & $1.27 \pm 0.03$ \\
\hline 6 & 0 & 0 & 0 & $22.21 \pm 0.67$ & $1.39 \pm 0.07$ \\
\hline 7 & 1 & $1(41)$ & 0 & $21.42 \pm 0.78$ & $1.18 \pm 0.06$ \\
\hline 8 & 0 & 1 & 1 & $13.43 \pm 0.87$ & $1.28 \pm 0.03$ \\
\hline 9 & 1 & 0 & -1 & $22.16 \pm 0.76$ & $1.30 \pm 0.10$ \\
\hline 10 & 0 & 1 & -1 & $16.29 \pm 0.81$ & $1.20 \pm 0.03$ \\
\hline 11 & 0 & -1 & -1 & $13.72 \pm 0.52$ & $1.29 \pm 0.07$ \\
\hline 12 & -1 & 1 & 0 & $11.21 \pm 0.54$ & $1.21 \pm 0.11$ \\
\hline 13 & 0 & -1 & 1 & $16.43 \pm 0.57$ & $1.27 \pm 0.08$ \\
\hline 14 & 0 & 0 & 0 & $20.77 \pm 0.75$ & $1.37 \pm 0.04$ \\
\hline 15 & -1 & -1 & 0 & $15.94 \pm 0.69$ & $1.21 \pm 0.05$ \\
\hline
\end{tabular}

Table 2. ANOVA for enzyme activity $\left(Y_{1}, \mathrm{U} / \mathrm{mL}\right)$ and specific activity $\left(Y_{2}, \mathrm{U} / \mathrm{mg}\right)$.

\begin{tabular}{|c|c|c|c|c|c|c|c|}
\hline \multirow{2}{*}{ Source } & \multirow{2}{*}{ DF } & \multicolumn{3}{|c|}{ Enzyme Activity $\left(Y_{1}, \mathrm{U} / \mathrm{mL}\right)$} & \multicolumn{3}{|c|}{ Specific Activity $\left(Y_{2}, \mathrm{U} / \mathrm{mg}\right)$} \\
\hline & & MS & $F$ & $\operatorname{Pr}>F$ & MS & $F$ & $\operatorname{Pr}>F$ \\
\hline Model & 9 & 20.73 & 10.99 & 0.0084 * & 0.0062 & 23.47 & 0.0014 * \\
\hline $\mathrm{X}_{1}$ & 1 & 70.69 & 37.47 & 0.0017 * & $<0.0001$ & 0.047 & 0.8366 \\
\hline$x_{2}$ & 1 & 0.022 & 0.012 & 0.9181 & 0.0018 & 6.79 & 0.0479 * \\
\hline$x_{3}$ & 1 & 6.66 & 3.53 & 0.1190 & 0.0015 & 5.71 & 0.0625 \\
\hline $\mathrm{X}_{1} \mathrm{X}_{2}$ & 1 & 26.57 & 14.09 & 0.0133 * & 0.0004 & 1.51 & 0.2739 \\
\hline$x_{1} x_{3}$ & 1 & 0.97 & 0.51 & 0.5054 & 0.0002 & 0.85 & 0.3991 \\
\hline$x_{2} X_{3}$ & 1 & 7.76 & 4.11 & 0.0984 & 0.0025 & 9.43 & 0.0277 * \\
\hline$X_{1}^{2}$ & 1 & 12.02 & 6.37 & 0.0529 & 0.015 & 56.63 & 0.0007 * \\
\hline$x_{2}^{2}$ & 1 & 40.20 & 21.31 & 0.0058 * & 0.038 & 142.84 & $<0.0001$ * \\
\hline$x_{3}^{2}$ & 1 & 31.91 & 16.91 & 0.0092 * & 0.0002 & 1.07 & 0.3490 \\
\hline Residual & 5 & 1.89 & & & 0.0002 & & \\
\hline Lack of fit & 3 & 2.64 & 3.47 & 0.2315 & 0.0001 & 0.44 & 0.7506 \\
\hline Pure error & 2 & 0.76 & & & 0.0004 & & \\
\hline $\mathrm{R}^{2}$ & & & 0.9519 & & & 0.9769 & \\
\hline $\mathrm{R}_{\text {adj }}^{2}$ & & & 0.8652 & & & 0.9352 & \\
\hline
\end{tabular}

* significant at $(p<0.05)$; DF: degrees of freedom; MS: mean square; F: F-value; $\operatorname{Pr}>F$ : $p$-value.

Equations (1) and (2) show the effect of time, temperature and buffer $\mathrm{pH}$ on enzyme activity and specific activity, respectively. The parameters of the equation are obtained by multiple regression analysis of the experimental data. The following quadratic model explains the experimental data:

$$
\begin{aligned}
& Y_{1}=21.21+2.97 X_{1}+0.052 X_{2}-0.91 X_{3}+2.58 X_{1} X_{2}-0.49 X_{1} X_{3}-1.39 X_{2} X_{3}-1.80 X_{1}^{2}-3.30 X_{2}^{2}-2.94 X_{3}^{2}, \\
& Y_{2}=1.37+0.0012 X_{1}-0.015 X_{2}+0.014 X_{3}-0.01 X_{1} X_{2}-0.0075 X_{1} X_{3}+0.025 X_{2} X_{3}-0.064 X_{1}^{2}-0.1 X_{2}^{2}-0.0087 X_{3}^{2},
\end{aligned}
$$

where $Y$ is the predicted response in actual value; $X_{1}$ is the uncoded value of variable time; $X_{2}$ is the uncoded value of variable temperature; $X_{3}$ is the uncoded value of variable buffer $\mathrm{pH}$.

As shown in Table 2, the model for enzyme activity of CEP from L. plantarum LP69 is significant $(p=0.0084 ;<0.05)$. The $p$-value of the lack of fit is more than 0.05 , which is not significant. Therefore, 
the model equation is confirmed to be a suitable model to describe the influence of three variables on enzyme activity. The value of determination coefficient $\left(R^{2}=95.19 \%\right)$ showed that only $4.81 \%$ of the variability in enzyme activity could not be explained by the model Equation (1). The $R^{2}$ adj value of 0.8652 close to the $R^{2}$ value showed the significance of the model, suggesting a good relationship between the predicted value and the actual value of enzyme activity.

The high significance for regression equation $(p=0.0014 ;<0.05)$ and insignificance for the lack of fit $(p=0.7506 ;>0.05)$ reveal the effectiveness of regression analysis, which suggest that the influence of three factors on specific activity could be fitted by the regression model. The model Equation (2) explains $97.69 \%$ of the variation in the specific activity according to the value of determination coefficient $\left(R^{2}=0.9769\right)$. The $\mathrm{R}^{2}$ adj value of 0.9352 close to the $\mathrm{R}^{2}$ value reveals the significance of the model, indicating a good relationship between the predicted value and the actual value of specific activity.

\subsubsection{The Influence of Time, Temperature and Buffer $\mathrm{pH}$ on the Response Value}

Two-dimensional contours reveal that enzyme activity and specific activity of CEP change with the changes of time, temperature and buffer $\mathrm{pH}$. The three-dimensional response surface is used to illustrate the interaction of the three variables and determine the optimal experimental conditions (Figures 1 and 2). $X_{1} X_{2}, X_{1} X_{3}$, and $X_{2} X_{3}$ have mutual interactions for the enzyme activity, since the contour plots seems to be elliptical or nearly circular (Figure 1). $X_{1}, X_{2}{ }^{2}$ and $X_{3}^{2}$ have a significant impact $(p<0.05)$ on the enzyme activity of CEP, revealing that there is not a simple linear relationship between the variables and enzyme activity. The $p$-value of $X_{1} X_{2}$ is smaller than 0.05 , which represents a significant interaction between time and temperature. $X_{1} X_{2}, X_{1} X_{3}$, and $X_{2} X_{3}$ have mutual interactions for the specific activity, because of their elliptical or nearly circular contour plots (Figure 2). The $p$-value of $X_{2} X_{3}$ is smaller than 0.05 , which represents a significant interaction between temperature and buffer $\mathrm{pH}$. Thus, the influence of one variable on specific activity depends on the level of another. The quadratic main effects of time and temperature are significant $\left(p \mathrm{X}_{1}^{2}=0.0007 ;<0.05, p \mathrm{X}_{2}^{2}<0.0001\right)$, suggesting that there is not a simple linear relationship between the variables and specific activity.

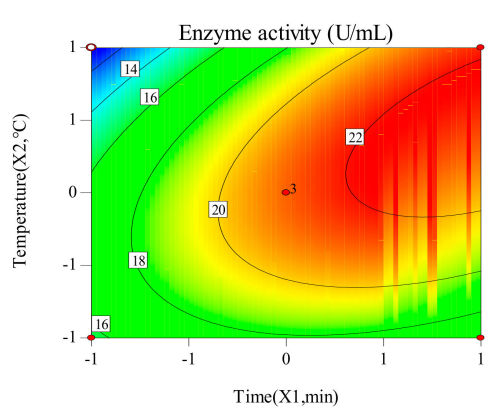

(a)

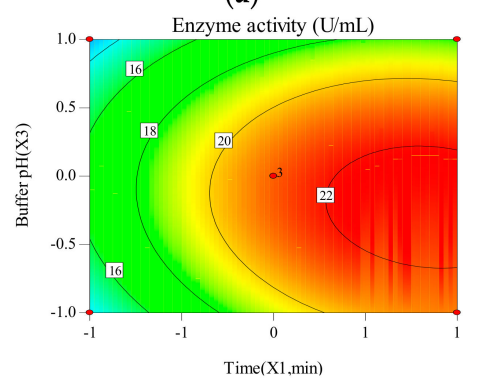

(c)

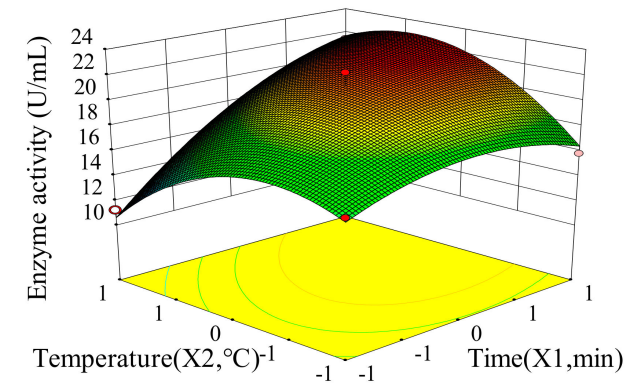

(b)

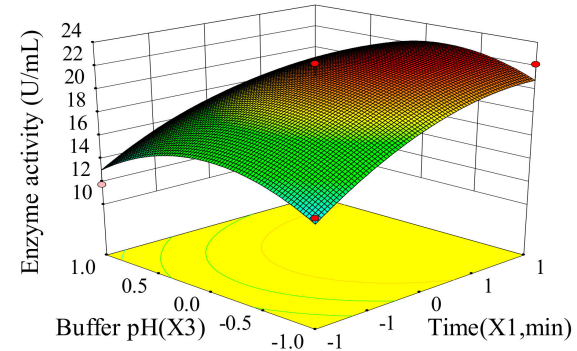

(d)

Figure 1. Cont. 


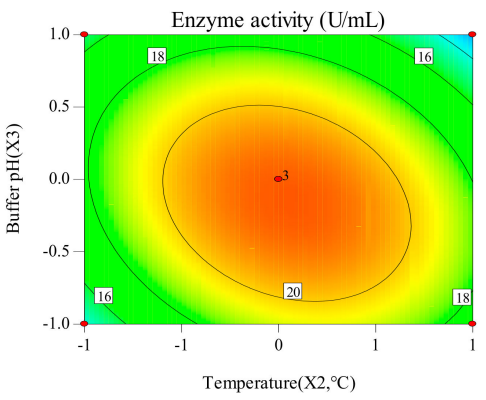

(e)

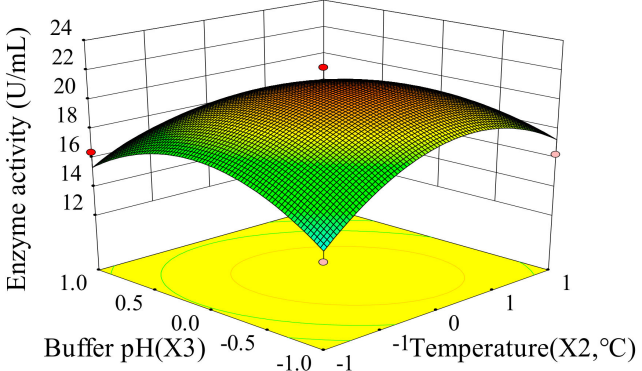

(f)

Figure 1. Contour plot of (a) time $\left(X_{1}\right)$ and temperature $\left(X_{2}\right)$; (b) time $\left(X_{1}\right)$ and buffer $\mathrm{pH}\left(X_{3}\right)$; (c) temperature $\left(X_{2}\right)$ and buffer $\mathrm{pH}\left(X_{3}\right)$ and 3D plot of $(\mathbf{d})$ time $\left(X_{1}\right)$ and temperature $\left(X_{2}\right)$; (e) time $\left(X_{1}\right)$ and buffer $\mathrm{pH}\left(X_{3}\right)$; (f) temperature $\left(X_{2}\right)$ and buffer $\mathrm{pH}\left(X_{3}\right)$ on enzyme activity of CEP from L. plantarum LP69.

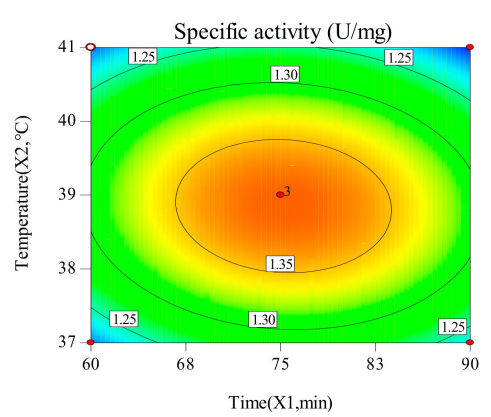

(a)

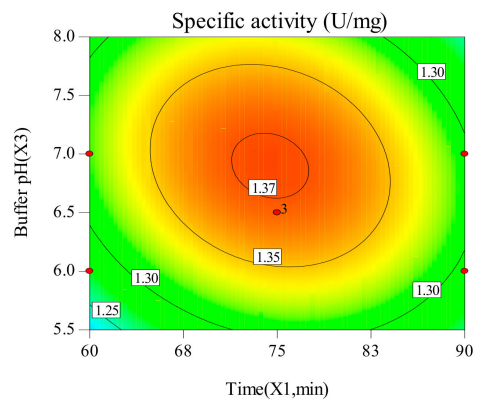

(c)

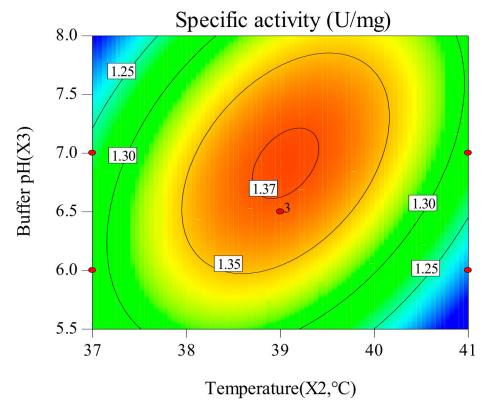

(e)

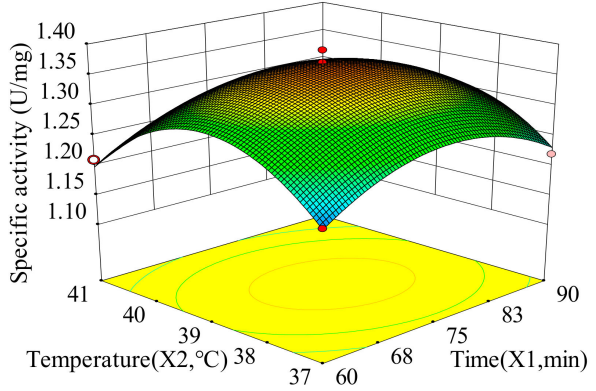

(b)

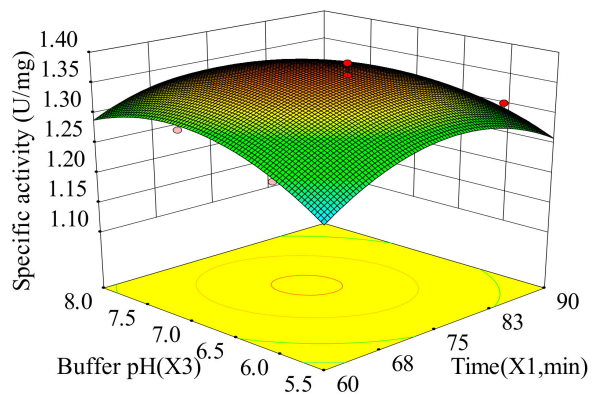

(d)

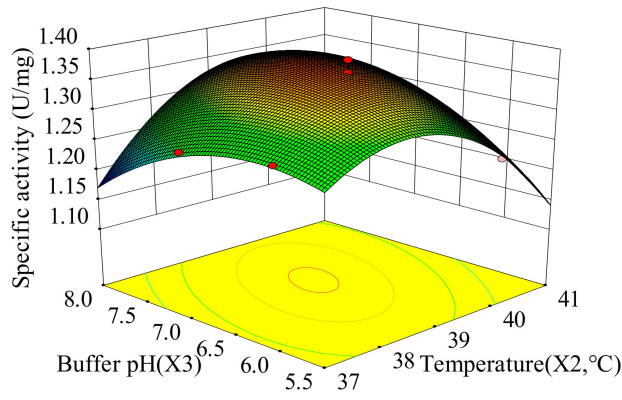

(f)

Figure 2. Contour plot of (a) time $\left(X_{1}\right)$ and temperature $\left(X_{2}\right)$; (b) time $\left(X_{1}\right)$ and buffer $\mathrm{pH}\left(X_{3}\right)$; (c) temperature $\left(X_{2}\right)$ and buffer $\mathrm{pH}\left(X_{3}\right)$ and $3 \mathrm{D}$ plot of $(\mathbf{d})$ time $\left(X_{1}\right)$ and temperature $\left(X_{2}\right) ;(\mathbf{e})$ time $\left(X_{1}\right)$ and buffer $\mathrm{pH}\left(\mathrm{X}_{3}\right)$; (f) temperature $\left(\mathrm{X}_{2}\right)$ and buffer $\mathrm{pH}\left(\mathrm{X}_{3}\right)$ on specific activity of CEP from L. plantarum LP69. 


\subsubsection{Model Validation}

The comparison between the actual value and the predicted value is used to reflect the accuracy of the response surface equations [21]. Figure $3 \mathrm{a}, \mathrm{b}$ shows the overall closeness of these variables, thus suggesting that the response surface model can be used to predict the effect of extraction parameters on enzyme activity and specific activity of CEP. The maximum response values of enzyme activity $(22.12 \mathrm{U} / \mathrm{mL})$ and specific activity $(1.36 \mathrm{U} / \mathrm{mg})$ of CEP from LP69 are obtained at a time of $80 \mathrm{~min}$, temperature of $39^{\circ} \mathrm{C}$ and buffer $\mathrm{pH}$ of 6.5 as the predicted values, respectively. The verification experiment is carried out according to the optimization results (time: $80 \mathrm{~min}$, temperature: $39^{\circ} \mathrm{C}$, buffer $\mathrm{pH}:$ 6.5). The results show that the mean value of enzyme activity and specific activity of CEP from LP69 were $(23.94 \pm 0.86) \mathrm{U} / \mathrm{mL}$ and $(1.37 \pm 0.03) \mathrm{U} / \mathrm{mg}$ by testing in triplicate, which is almost consistent with the predicted values. The control has values of CEP enzyme activity as $20.64 \mathrm{U} / \mathrm{mL}$ and specific activity as $1.19 \mathrm{U} / \mathrm{mg}$ without optimizing extraction conditions. The enzyme activity and specific activity are improved by $15.99 \%$ and $15.13 \%$ using RSM optimization compared to the control.

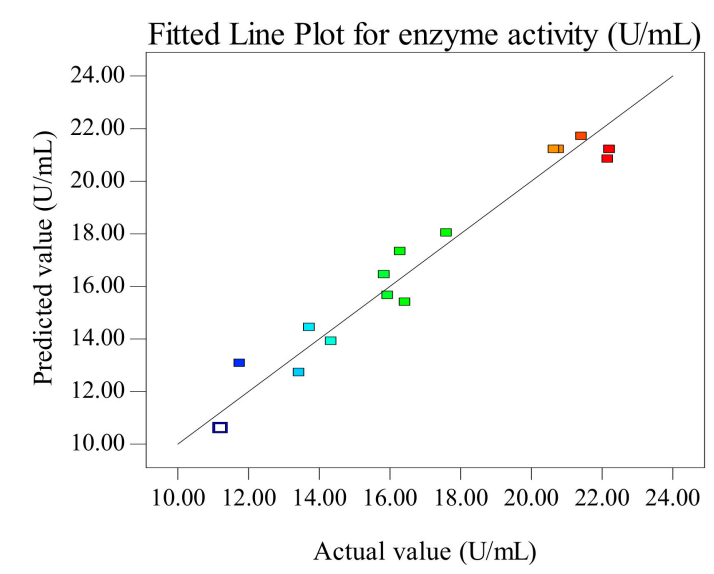

(a)

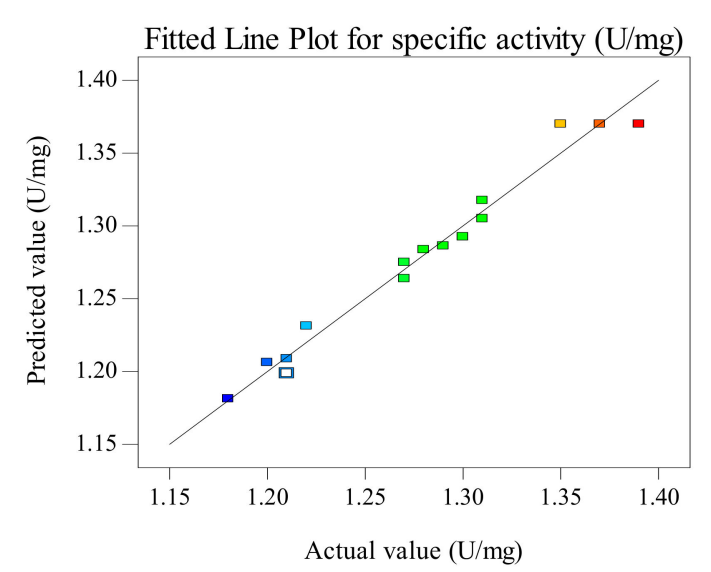

(b)

Figure 3. Fitted line plot showing the closeness between predicted values and actual values for enzyme activity (a) and specific activity (b) of CEP from L. plantarum LP69.

\subsection{Enzymatic Properties of CEP}

\subsubsection{Effects of $\mathrm{pH}$ and Temperature on Enzyme Activity}

The enzymatic properties of CEP from L. plantarum LP69 are studied. The results from Figure 4a indicate that the maximum activity of $27.85 \mathrm{U} / \mathrm{mL}$ is obtained at $\mathrm{pH} 8.0$ and the relative enzyme activity reaches $100 \%$. It maintains $93 \%$ of the maximum activity in the range of $\mathrm{pH} 7.5-8.5$. Figure $4 \mathrm{~b}$ shows that less than $60 \%$ of the relative enzyme activity is assayed at $\mathrm{pH} 6.0$ or 10.0 when incubated for $30 \mathrm{~min}$, but more than $70 \%$ of the relative enzyme activity is observed in the range of $\mathrm{pH} 7.0-9.0$. Thus, the enzyme exhibits good stablity when incubated for $30 \mathrm{~min}$ in the $\mathrm{pH}$ range 7.0-9.0. Moreover, it has high activity at temperatures ranging from 36 to $44{ }^{\circ} \mathrm{C}$. The CEP has a maximum activity $(26.15 \mathrm{U} / \mathrm{mL})$ at $40{ }^{\circ} \mathrm{C}$ and its relative enzyme activity reaches $100 \%$ (Figure $5 \mathrm{a}$ ). The relative enzyme activity of CEP is still $28.84 \%$ in $80{ }^{\circ} \mathrm{C}$ for $30 \mathrm{~min}$ (Figure $5 \mathrm{~b}$ ), which indicates that the enzyme has a good anti-heat ability. 


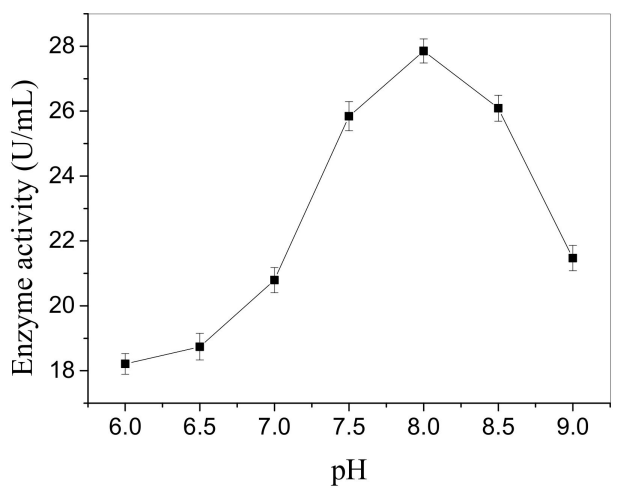

(a)

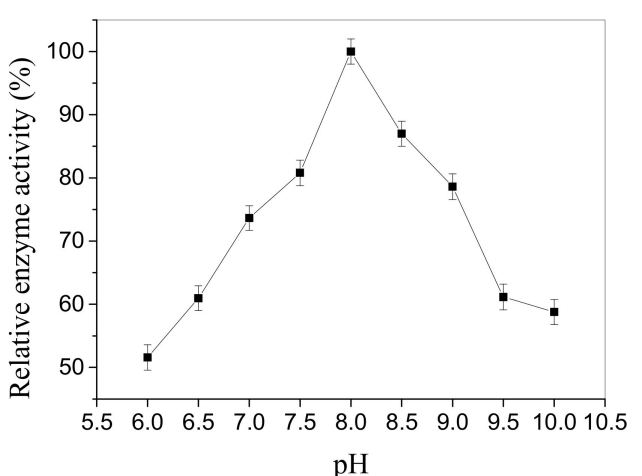

(b)

Figure 4. Influence of $\mathrm{pH}$ on activity of the CEP (a) and relative enzyme activity of CEP after $30 \mathrm{~min}$ incubation at $\mathrm{pH}$ ranging from 6.0 to $10.0(\mathbf{b})$. The error bars express standard deviation of average value $(n=3)$.

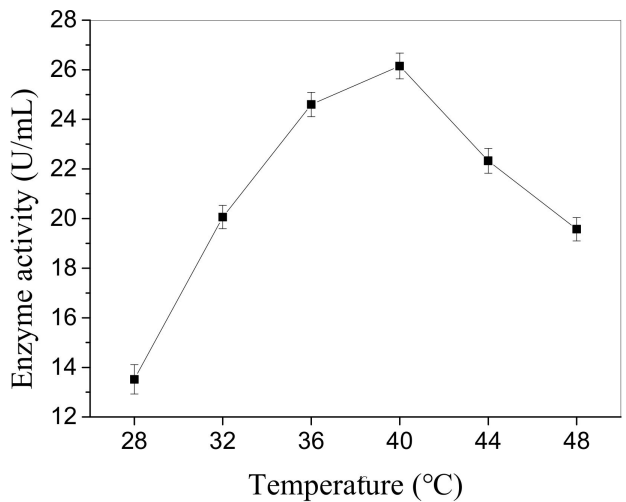

(a)

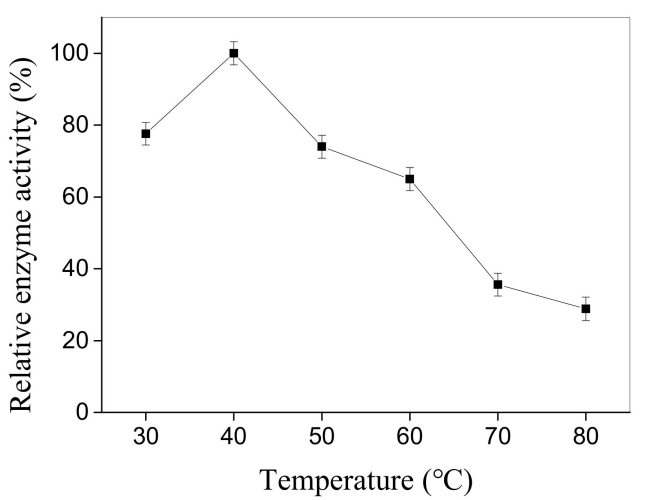

(b)

Figure 5. Influence of temperature on activity of the CEP (a) and relative enzyme activity of CEP after $30 \mathrm{~min}$ incubation at temperatures ranging from 30 to $80^{\circ} \mathrm{C}(\mathbf{b})$. The error bars express standard deviation of average value $(n=3)$.

\subsubsection{Effect of Metal Ions and Inhibitors on Enzyme Activity}

The effects of various compounds on the enzyme activity are shown in Table 3. The enzyme is activated by $\mathrm{Ca}^{2+}$ and it can be strongly activated by $\mathrm{Ca}^{2+}$ to $122.82 \%$ with a concentration of $10 \mathrm{mM}$. Na ${ }^{+}, \mathrm{Zn}^{2+}$, EDTA and PMSF have significant inhibitory effects on enzyme activity. The presence of $1 \mathrm{mM} \mathrm{K}^{+}$inhibits the activity of the CEP, while the enzyme is activated at a concentration of $10 \mathrm{mM}$ of $\mathrm{K}^{+}$.

\subsubsection{Kinetic Studies of CEP}

According to the linear Lineweaver-Burk plot of $1 / \mathrm{V}$ against $1 /[\mathrm{S}]$, the values of kinetic parameters $K_{\mathrm{m}}$ and $V_{\max }$ for the CEP from L. plantarum LP69 are measured. When whey protein is used as a substrate, at a $\mathrm{pH}$ of 8 , temperature of $40^{\circ} \mathrm{C}$, and enzyme-to-substrate ratio (E/S) of $10 \%$ $(w / w)$, the kinetic parameter $K_{\mathrm{m}}$ is $0.745 \mathrm{mg} / \mathrm{mL}$ and $V_{\max }$ is $0.479 \mathrm{mg} / \mathrm{mL} \cdot \mathrm{min}$ (Figure 6a). It could be seen from Figure $6 \mathrm{~b}$ that the $K_{\mathrm{m}}$ and $V_{\max }$ of CEP are $0.332 \mathrm{mg} / \mathrm{mL}$ and $0.228 \mathrm{mg} / \mathrm{mL} \cdot \mathrm{min}$ when lactoglobulin is employed as a substrate. Figure $6 c$ shows the $K_{\mathrm{m}}$ and $V_{\max }$ of CEP are $1.176 \mathrm{mg} / \mathrm{mL}$ and $0.798 \mathrm{mg} / \mathrm{mL} \cdot \mathrm{min}$ with casein as the substrate. 
Table 3. Influence of various concentrations of metal ions and inhibitors on the crude CEP activity of L. plantarum LP69.

\begin{tabular}{ccc}
\hline \multirow{2}{*}{ Inhibitors and Ions } & \multicolumn{2}{c}{ Relative Enzyme Activity (\%) } \\
\cline { 2 - 3 } & \multicolumn{2}{c}{ Compound Concentration $(\mathbf{m M})$} \\
\cline { 2 - 3 } & $\mathbf{1 . 0 0}$ & $\mathbf{1 0 . 0 0}$ \\
\hline None & 100.00 & 100.00 \\
$\mathrm{Ca}^{2+}$ & 105.96 & 122.82 \\
$\mathrm{Na}^{+}$ & 91.42 & 93.75 \\
$\mathrm{~K}^{+}$ & 94.23 & 106.01 \\
$\mathrm{Zn}^{2+}$ & 53.59 & 42.34 \\
PMSF & 40.94 & 25.73 \\
EDTA & 45.20 & 34.93 \\
\hline
\end{tabular}

The crude CEP activity was the average of three replicates twice analyzed. ${ }^{a}$ PMSF, phenylmethylsulfonyl fluoride; EDTA, ethylene-diamine-tetra-acetic acid. ${ }^{\mathrm{b}}$ The activity of the control in the absence of chemical reagents and metal ions was taken as $100 \%$.

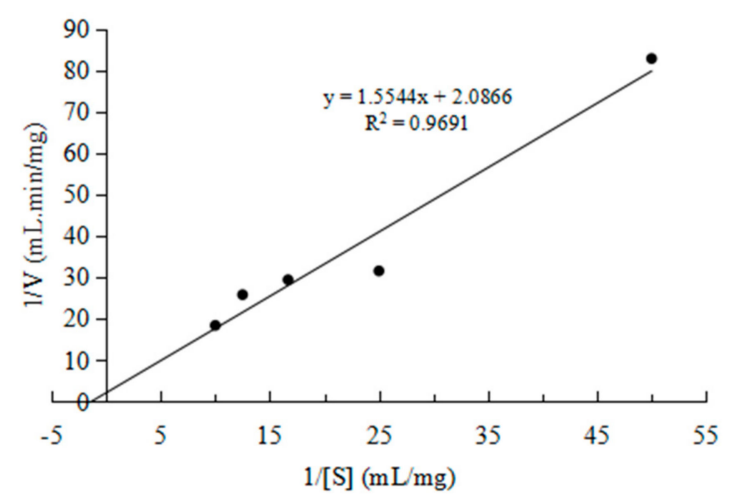

(a)

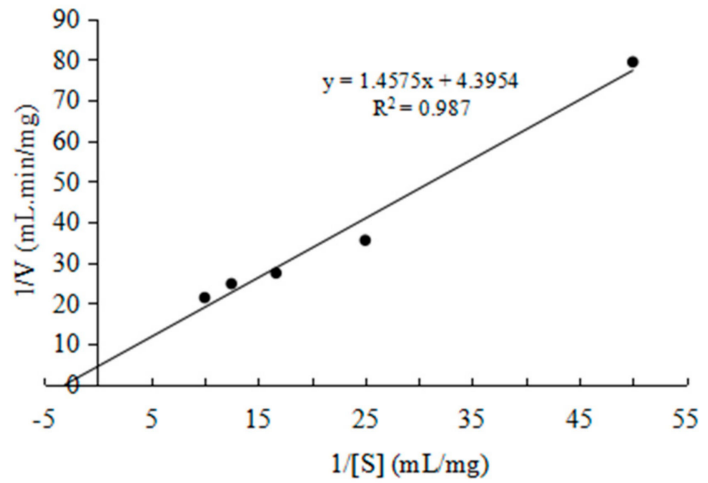

(b)

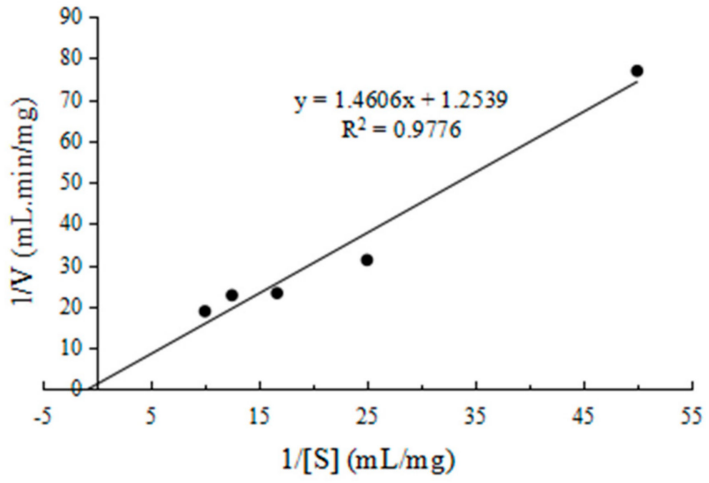

(c)

Figure 6. Determination of Lineweaver-Burk graph for CEP from L. plantarum LP69 at five different concentrations of various substrates (a) whey protein, (b) lactoglobulin and (c) casein.

\section{Discussion}

There exists a direct relationship between the total activity of the crude CEP and the specific activity in Equation (3). It suggests that higher levels of enzyme activity cause an increase in the specific activity. Our study found that time has the most positive $(p=0.0017 ;<0.05)$ effect on enzyme activity of CEP (Table 2). Time is an important parameter for the CEP extraction because an inappropriate time can disrupt the natural structure of the enzyme and leads to a decrease in enzyme activity. Besides, long incubation times will contribute to a high processing cost. The results indicate that the best time for extracting CEP from LP69 is $80 \mathrm{~min}$. Mehrnoush et al. [21] reported that the incubation time affected the total activity of the CEP; in fact, increasing the incubation time above the optimum point caused 
the protein/enzyme to denature due to the loss of tertiary structure. In addition, increasing the time led to the emergence of unwanted proteins or contaminants in the extracted sample. The temperature has the most significant $(p=0.0479 ;<0.05)$ impact on the specific activity of CEP. The temperature of $39^{\circ} \mathrm{C}$ is the desirable temperature to release CEP of LP69. A higher or lower temperature will cause the decline of activity and stability of proteinases [22]. A study reported that the attachment of some cell-surface proteins to bacterial cells is dependent on $\mathrm{pH}$, and these surface proteins were usually attached/released at neutral or slightly alkaline $\mathrm{pH}$ [5]. This $\mathrm{pH}$ dependency implies that extraction agents must be used at the optimal $\mathrm{pH}$. Figure 2 shows that the maximum specific activity $(1.36 \mathrm{U} / \mathrm{mg})$ of CEP is obtained at $\mathrm{pH}$ of 6.5 .

The optimal $\mathrm{pH}$ of CEP is in the range of 7.5-8.5. Besides, the enzyme activity of CEP in the range of $\mathrm{pH} 6.0-7.5$ decreased faster than that at $\mathrm{pH}$ of $8.5-10.0$, indicating that the proteinase is more stable under alkaline conditions compared to under acidic conditions. It is, therefore, assumed that $\mathrm{CEP}$ is an alkaline proteinase. The enzyme shows an optimal activity at $\mathrm{pH}$ of 8.0 , which is consistent with the optimal condition for CEP from L. fermentium [23]. However, the optimum $\mathrm{pH}$ of some Lactobacillus CEP was in the range of 5-7.5, such as L. helveticus CP790 [23], L. delbrueckii ssp. lactis ACA-DC178 [4] and Lactococcus lactis ssp. lactis LB12 [1]. It suggestes that optimum pH of CEP is dependent on LAB strains. The highest proteinase acticity was obtained at $40^{\circ} \mathrm{C}$, which is the same as that for the CEP extracted from L. helveticus CP790 [23], L. delbrueckii ssp. lactis ACA-DC178 [4] and Lactococcus lactis ssp. lactis LB12 [1]. Besides, our enzyme is found to be more stable than that isolated from L. casei ssp. casei IFPL731 [24] which exhibited a 50\% loss of activity at $35^{\circ} \mathrm{C}$ and a total loss at $50{ }^{\circ} \mathrm{C}$ after incubating for $30 \mathrm{~min}$. Crude CEP has good thermal stability when heated with the substrate.

The enzyme is activated by $\mathrm{K}^{+}, \mathrm{Ca}^{2+}$ and inhibited by $\mathrm{Na}^{+}, \mathrm{Zn}^{2+}$ and EDTA, suggesting that CEP is a metallopeptidase. Because its activity is inhibited by the serine proteinase inhibitor PMSF, CEP is assumed to be a serine proteinase. However, PMSF shows higher \% inhibition than EDTA. Based on only this data, serine proteinase might be the major proteinase. In this study, we observe that CEP from L. plantarum LP69 can be released from the cell surface when incubated in the $\mathrm{Ca}^{2+}$-free buffer and the enzyme activity is measured of $20.35 \mathrm{U} / \mathrm{mL}$. EDTA is a metal-chelator. It could chelate metal calcium ions. The removal of $\mathrm{Ca}^{2+}$ in CEP initates a structural rearrangement in the proteinase domain, causing the release of the enzyme from the cell surface and a lower specific activity. Genov et al. [25] observed four $\mathrm{Ca}^{2+}$-binding sites in LAB-related serine proteinases (subtilases) and found that the association of $\mathrm{Ca}^{2+}$ with these sites affected the activity and thermal stability of the proteinases and protected the enzymes from autoproteolytic degradation. Another study reported that the presence of $\mathrm{Ca}^{2+}$ ions could stabilize the CEP activity after release, which is consistent with the result of our finding [1]. Our study found that the relative activity of CEP is significantly increased to $105.96 \%$ and $122.82 \%$ in present of $1 \mathrm{mM}$ and $10 \mathrm{mM} \mathrm{Ca}^{2+}$ ions, respectively. It indicates that the CEP from L. plantarum LP69 is a $\mathrm{Ca}^{2+}$ dependent enzyme and its active site is related to metal ions.

Enzymatic hydrolysis is an extensively used method, which contributes to the production of protein hydrolysates with improved functional, nutritional and physiological properties [26]. Corrochano et al. [27] have confirmed that hydrolysates from whey proteins exhibit radical scavenging activity and reducing power. Furthermore, whey protein hydrolysate hydrolyzed by the purified CEP showed strong ACE-inhibitory activity [1]. A previous study [28] indicated that proteolytic products of $\beta$-lactoglobulin catalyzed by both pepsin and trypsin have antioxidant activity. Rezvan et al. [29] found that the proteases produced by Lactcoccus lactis subsp. cremoris and Lactcoccus lactis subsp. hordniea reduce significantly the allergenicity of lactoglobulin. Kumarb et al. [30] studied camel milk casein hydrolysates catalyzed by Alcalase, $\alpha$-Chymotrypsin and Papain. They found that all the three hydrolysates had antioxidant activity. Our study found that CEP from LP69 is able to hydrolyze whey protein, lactoglobulin and casein (Figure 6). Kinetics parameter $\mathrm{K}_{\mathrm{m}}$ values show that CEP has strong affinity with lactoglobulin, followed by whey protein. CEP and casein have the worst binding ability. Furthermore, $V_{\max }$ values show that casein has the maximum reaction rate, followed by whey 
protein and lastly lactoglobulin. The maximum reaction rate of lactoglobulin catalyzed by CEP is low. It might be due to the lactoglobulin having a compact and globular (ellipsoidal) structure which could prevent the proteinase from contacting the internal peptide bonds [31]. It demonstrates CEP has a good potential for the production of bioactive peptides-rich dairy products.

\section{Materials and Methods}

\subsection{Strains and Chemicals}

L. plantarum LP69 was isolated from fermented bovine milk from Inner Mongolia, China and conserved by the School of Food and Biological Engineering, Shaanxi University of Science \& Technology. The Man Rogosa Sharpe (MRS) broth was purchased from Land Bridge Technology Co., Ltd (Beijing, China). Whey protein, lactoglobulin and casein were obtained from Aoboxing Bio-tech Co., Ltd (Beijing, China). Phenylmethylsulphonyl fluoride (PMSF) and ethylene-diamine-tetra-acetic acid (EDTA) were purchased from Sigma Chemicals Co. Ltd. (St. Louis, MO, USA). Other chemicals were from Hongyan chemical reagent factory (Tianjin, China).

\subsection{Preparation of Cell-Free Extracts of L. Plantarum LP69}

L. plantarum LP69 was inoculated 5\% $(v / v)$ into MRS broth and subcultured twice in MRS broth at $37^{\circ} \mathrm{C}$; final growth was incubated at $37^{\circ} \mathrm{C}$ for $22 \mathrm{~h}$. Cells were collected by centrifugation at $6000 \times \mathrm{g}$ for 15 min at $4{ }^{\circ} \mathrm{C}$ (Model GL21, Instrumentation, Hunan, China). The pellet was washed three times with $50 \mathrm{mM}$ Tris- $\mathrm{HCl}$ buffer ( $\mathrm{pH} 7.8$ ) in the presence of $30 \mathrm{mM} \mathrm{CaCl}_{2}$. The cells were resuspended in $50 \mathrm{mM}$ Tris- $\mathrm{HCl}$ buffer containing $50 \mathrm{mM}$ EDTA-Na $\mathrm{N}_{2}$ at $\mathrm{pH}$ 6-7 and incubated at different temperatures $\left(37-41{ }^{\circ} \mathrm{C}\right)$ for $60-90 \mathrm{~min}$. The cells were cooled to room temperature (RT) and centrifuged at $6000 \times g$ for $15 \mathrm{~min}$ at $4{ }^{\circ} \mathrm{C}$, after which the clear supernatant was collected and was designated as the cell-free extracts to determine enzyme activity, protein contents and specific activity.

\subsection{Determination of Enzyme Activity}

Enzyme activity was measured as described by the method of Folin [32] with some modifications. The reaction mixture consisted of $1 \mathrm{~mL}$ of the cell-free extracts and $1 \mathrm{~mL}$ of substrate solution ( $2 \mathrm{mg} / \mathrm{mL}$ casein in $50 \mathrm{mM}$ sodium phosphate buffer; $\mathrm{pH} 7.0$ ). After incubating at $40^{\circ} \mathrm{C}$ for $10 \mathrm{~min}$, the reaction was terminated by the addition of $2 \mathrm{~mL}$ of $65.4 \mathrm{~g} / \mathrm{L}$ trichloroacetic acid (TCA) followed by centrifugation $(6000 \times \mathrm{g}, 5 \mathrm{~min})$. Then, the mixture of $1 \mathrm{~mL}$ supernatant, $5 \mathrm{~mL}$ of $42.4 \mathrm{~g} / \mathrm{L} \mathrm{Na}_{2} \mathrm{CO}_{3}$ and $1 \mathrm{~mL}$ of $2 \mathrm{~N}$ Folin and Ciocalteu's reagent was incubated for $20 \mathrm{~min}$ at $40{ }^{\circ} \mathrm{C}$ in water bath. The release of tyrosine was determined by measuring absorbance at $680 \mathrm{~nm}$. One enzyme activity unit (U) was expressed as hydrolyzing casein to produce $1.0 \mu \mathrm{M}(181 \mu \mathrm{g})$ of tyrosine per hour at $\mathrm{pH} 7.0$ at $40^{\circ} \mathrm{C}$. The blank control replaced the enzyme solution with buffer.

\subsection{Determination of Protein Concentration}

Protein contents of the cell free extracts were estimated by the method of Bradford [33] using the Coomassie Brilliant Blue G-250 and bovine serum albumin as the standard.

\subsection{Specific Activity Assay}

The specific activity of the cell free extracts $(\mathrm{U} / \mathrm{mg})$ was determined by the ratio of the total enzyme activity of the cell free extracts $(\mathrm{U})$ and total protein $(\mathrm{mg})$ [34]:

$$
\text { Specific activity }(\mathrm{U} / \mathrm{mg})=\frac{\text { Total enzyme activity }(\mathrm{U})}{\text { Total protein }(\mathrm{mg})}
$$




\subsection{Experimental Design}

In the previous study, the influence of main extraction parameters had been settled through Plackett-Burman design. Time, temperature and buffer $\mathrm{pH}$ were selected as the best extraction parameters for L. plantarum LP69. Moreover, the optimal range of these parameters was screened by path steepest ascent experiment. Thus, a Box-Behnken design (BBD) was used for exploring the optimal extraction conditions of CEP from L. plantarum LP69 and the interactions of these variables. The BBD was applied with three factors and three levels (15 experiments with three replicates at the central points). Indeed, for each of the three selected factors, three levels $(-1,0$ and 1$)$ were allocated: time (60-90 $\left.\mathrm{min}, \mathrm{X}_{1}\right)$, temperature $\left(37-41^{\circ} \mathrm{C}, \mathrm{X}_{2}\right)$ and buffer $\mathrm{pH}\left(6-7, \mathrm{X}_{3}\right)$. The factors level was shown in Table 4. All tests and measurements were performed three more times, and the average of enzyme activity and specific activity was selected as the response $(Y)$. Second-degree polynomial equation was set to evaluate fitness of data and the response value was calculated by the following quadratic equation:

$$
Y=\beta_{o}+\sum \beta_{i} X_{i}+\sum \beta_{i i} X_{i}^{2}+\sum \beta_{i j} X_{i} X_{j}
$$

where $Y$ is the predicted value of the dependent variable, $\beta_{\mathrm{o}}$ is the second-order reaction constant terms, $\beta_{i}$ is the linear terms coefficient, $\beta_{i i}$ is quadratic terms coefficient and $\beta_{i j}$ is interaction terms coefficient; $X_{i}$ and $X_{j}$ are the independent variables.

Table 4. Factors and levels of the experimental design for CEP extraction conditions.

\begin{tabular}{ccccc}
\hline \multirow{2}{*}{ Factors } & \multirow{2}{*}{ Symbol } & \multicolumn{3}{c}{ Coded Levels } \\
\cline { 3 - 5 } & & $\mathbf{- 1}$ & $\mathbf{0}$ & $\mathbf{1}$ \\
\hline Time $(\mathrm{min})$ & $\mathrm{X}_{1}$ & 60 & 75 & 90 \\
Temperature $\left({ }^{\circ} \mathrm{C}\right)$ & $\mathrm{X}_{2}$ & 37 & 39 & 41 \\
Buffer $\mathrm{pH}$ & $\mathrm{X}_{3}$ & 6.0 & 6.5 & 7.0 \\
\hline
\end{tabular}

\subsection{Enzymatic Properties of CEP from L. plantarum LP69}

\subsubsection{Effect of $\mathrm{pH}$ on the Enzyme Activity}

The influence of $\mathrm{pH}$ in the range $6.0-9.0$ was measured at $37^{\circ} \mathrm{C}$ with casein as substrate, using $50 \mathrm{mM}$ Tris- $\mathrm{HCl}$ buffer. To check the $\mathrm{pH}$ stability of the enzyme, the enzyme was dissolved in $50 \mathrm{mM}$ Tris- $\mathrm{HCl}$ buffer within the $\mathrm{pH}$ range $6.0-10.0$ and incubated for $30 \mathrm{~min}$ at $37^{\circ} \mathrm{C}$. The relative enzyme activity was subsequently determined at $37^{\circ} \mathrm{C}$. The relative activity of CEP was determined by taking the ratio of actual enzyme activity and the maximum enzyme activity.

\subsubsection{Temperature Optimum}

Enzyme activity were measured in $50 \mathrm{mM}$ Tris- $\mathrm{HCl}$ buffer $(\mathrm{pH} 7.8)$ at different temperatures from 28 to $48{ }^{\circ} \mathrm{C}$, using casein as the substrate. The enzyme solutions were incubated for $30 \mathrm{~min}$ at temperatures ranging from 30 to $80^{\circ} \mathrm{C}$ to evaluate the thermal stability of the CEP. The relative enzyme activity was subsequently assayed at $37^{\circ} \mathrm{C}$ with casein as the substrate.

\subsubsection{Influence of Metal Ions and Inhibitors on Enzyme Activity}

The enzyme was pre-incubated with different metal ions $\left(\mathrm{Na}^{+}, \mathrm{K}^{+}, \mathrm{Zn}^{2+}\right.$ and $\left.\mathrm{Ca}^{2+}\right)$ and inhibitors (PMSF and EDTA) for $30 \mathrm{~min}$ at $37^{\circ} \mathrm{C}$, at a final concentration of $1.0 \mathrm{mM}$ and $10.0 \mathrm{mM}$ in $50 \mathrm{mM}$ Tris- $\mathrm{HCl}$ buffer ( $\mathrm{pH} 7.8)$, respectively. The activity was then assayed at $37^{\circ} \mathrm{C}$ using casein as substrate. Controls were used to eliminate the interference of inhibitors or metal ions. 


\subsubsection{Kinetic Studies of CEP}

The standard tetrapeptide Gly-Gly-Tyr-Arg was dissolved in 5\% TCA solution and was formulated into various concentrations $(0.0,0.2,0.4,0.6,0.8,1.0,1.2,1.4,1.6$, and $1.8 \mathrm{mg} / \mathrm{mL})$, respectively. $6 \mathrm{~mL}$ of the above solution was mixed with $4 \mathrm{~mL}$ of biuret reagent. The mixture was cooled to RT and centrifuged at $6000 \times g$ for $10 \mathrm{~min}$. The absorbance of the sample was measured at $540 \mathrm{~nm}$ using a UV/Vis spectrophotometer (Shanghai Spectrum Instruments Co., Ltd., Shanghai, China), drawn the standard curve.

Three substrates of whey protein, lactoglobulin and casein were formulated into different concentrations of $0.02,0.04,0.06,0.08,0.10 \mathrm{mg} / \mathrm{mL}$, respectively. The hydrolysis conditions of three substrates were temperature of $40{ }^{\circ} \mathrm{C}, \mathrm{pH}$ of 8 and $E / S$ of $10 \%(w / w)$. When the hydrolysis time was between $0 \mathrm{~min}$ and $9 \mathrm{~min}$, it was sampled every $3 \mathrm{~min}$. The reaction was stopped by heating under $90^{\circ} \mathrm{C}$. The absorbance at $540 \mathrm{~nm}$ of supernatant was measured to determine the protein contents after centrifuging at $10,664 \times g$ for $15 \mathrm{~min}$. The production of protein reflected the initial speed of enzymatic reaction [35].

The $K_{\mathrm{m}}$ and $V_{\max }$ values were determined from a Lineweaver-Burk plot of the kinetic data. The model of the Lineweaver-Burk equation was as follows [36]:

$$
\frac{1}{V}=\frac{K_{\mathrm{m}}}{V_{\max }} \times \frac{1}{[S]}+\frac{1}{V_{\max }}
$$

where $V$ was the reaction rate, $K_{\mathrm{m}}$ was the Michaelis-Menten constant, $V_{\max }$ was the maximum reaction rate, and $[S]$ was the substrate concentration.

\subsection{Statistical Analysis}

Data from three replicated trials for each treatment are presented as means with standard deviation (Mean \pm SD). All modeling and Statistical analysis were performed using Design of Expert software (Version 8.0.6, Stat-Ease Corp., Minneapolis, MN, USA), and differences were considered statistically significant at $p<0.05$. The Origin 9 software package (Origin Lab Inc., Alexandria, VA, USA) and Microsoft Excel 2010 (Redmond, WA, USA) were used for describing enzyme properties.

\section{Conclusions}

In the present study, the influence of three main factors on the extraction of CEP from L. plantarum LP69 was investigated by RSM. Time has the most significant $(\mathrm{p}<0.05)$ impact on enzyme activity of CEP. Inappropriate time could disrupt the natural structure of the proteinase and cause a high processing cost. The temperature has the most significant $(p<0.05)$ influence on specific activity. A higher or lower temperature led to loss of the activity and stability of proteinases. The release of CEP from LP69 was also affected by buffer $\mathrm{pH}$. The results suggest that the optimum extraction conditions of CEP from L. plantarum LP69 were achieved using a temperature of $39^{\circ} \mathrm{C}$, time of $80 \mathrm{~min}$, and buffer $\mathrm{pH}$ of 6.5. The optimized conditions result in an increase in enzyme activity and specific activity of the CEP to $(23.94 \pm 0.86) \mathrm{U} / \mathrm{mL}$ and $(1.37 \pm 0.03) \mathrm{U} / \mathrm{mg}$, respectively. The maximum activity of crude $\mathrm{CEP}$ is obtained at $\mathrm{pH} 8.0$ and $40^{\circ} \mathrm{C}$. The CEP is a metallopeptidase, since it is activated by $\mathrm{Ca}^{2+}$ and inhibited by $\mathrm{Zn}^{2+}$ and EDTA. It is a serine proteinase which is inhibited by PMSF. The CEP was able to hydrolyze whey protein, lactoglobulin and casein, which demonstrates it has a good potential for the production of bioactive peptide-rich dairy products.

Author Contributions: H.C. and L.C. conceived and designed the experiments; J.H. and N.L. performed the experiments; N.S. analyzed the data; H.C. and B.C. contributed reagents/materials/analysis tools; J.H. wrote the paper.

Funding: This research was funded by the Science and Technology Project of Xianyang city (No. 2017K02-69) and the Science and Technology Overall Planning for innovation Engineering project of Shaanxi Province (No. 2016KTZDNY02-03).

Acknowledgments: This work was partly supported by the Scientific Research Program Funded by Shaanxi Provincial Education Department (No. 17JF005), which are greatly acknowledged.

Conflicts of Interest: The authors declare no conflict of interest. 


\section{References}

1. Guo, Y.X.; Pan, D.D.; Zeng, X.Y.; Tanokura, M. Purification and characterization of CEP from Lactococcus lactis ssp. Lactis. Food Chem. 2009, 112, 533-538. [CrossRef]

2. Fung, W.Y.; Liong, M.T. Evaluation of proteolytic and ACE-inhibitory activity of Lactobacillus acidophilus in soy whey growth medium via response surface methodology. LWT Food Sci. Technol. 2010, 43, 563-567. [CrossRef]

3. Espeche, T.M.B.; Savoy de Giori, G.; Hebert, E.M. Release of the cell-envelope-associated proteinase of Lactobacillus delbrueckii subspecies lactis CRL 581 is dependent upon $\mathrm{pH}$ and temperature. J. Agric. Food Chem. 2009, 57, 8607-8611. [CrossRef] [PubMed]

4. Tsakalidou, E.; Anastasiou, R.; Vandenberghe, I.; van Beeumen, J.; Kalantzopoulos, G. Cell-wall-bound proteinase of Lactobacillus delbrueckii subsp. lactis ACA-DC 178: Characterization and specificity for $\beta$-casein. Appl. Environ. Microbiol. 1999, 65, 2035-2040. [PubMed]

5. Sánchez, B.; Bressollier, P.; Chaignepain, S.; Schmitter, J.M.; Urdaci, M.C. Identification of surface-associated proteins in the probiotic bacterium Lactobacillus rhamnosus GG. Int. Dairy J. 2009, 19, 85-88. [CrossRef]

6. Jarocki, P.; Podlesny, M.; Wasko, A.; Siuda, A.; Targonski, Z. Differentiation of three Lactobacillus rhamnosus strains (E/N, Oxy and Pen) by SDS-PAGE and two-dimensional electrophoresis of surface-associated proteins. J. Microbiol. Biotechnol. 2010, 20, 558-562. [PubMed]

7. Fira, D.; Kojic, M.; Banina, A.; Spasojevic, I.; Strahinic, I.; Topisirovic, L. Characterization of cell envelope-associated proteinases of Thermophilic lactobacilli. J. Appl. Microbiol. 2001, 90, 123-130. [CrossRef] [PubMed]

8. Laloi, P.; Atlan, D.; Blanc, B.; Gilbert, C.; Portalier, R. Cell-wall-associated proteinase of Lactobacillus delbrueckii subsp. bulgaricus CNRZ397: differential extraction, purification and properties of the enzyme. Appl. Microbiol. Biotechnol. 1991, 36, 196-204.

9. MartÍn-Hernández, M.C.; Alting, A.C.; Exterkate, F.A. Purification and characterization of the mature, membrane-associated cell-envelope proteinase of Lactobacillus helveticus L89. Appl. Microbiol. Biotechnol. 1994, 40, 828-834. [CrossRef]

10. Hébert, E.M.; Raya, R.; de Giori, G.S. Characterization of a cell membrane-associated proteinase from Lactobacillus helveticus CRL 581. Curr. Microbiol. 1997, 35, 161-164. [CrossRef]

11. Bhowmik, T.; Johnson, M.C.; Ray, B. Isolation and partial characterization of the surface protein of Lactobacillus acidophilus strains. Int. J. Food Microbiol. 1985, 2, 311-321. [CrossRef]

12. Atlan, D.; Laloi, P.; Portalier, R. X-prolyl-dipeptidylamino peptidase of Lactobacillus delbrueckii subsp. bulgaricus: Characterization of the enzyme and isolation of deficient mutants. Appl. Environ. Microbiol. 1990, 56, 2174-2179. [PubMed]

13. Agyei, D.; Lim, W.; Zass, M.; Tan, D.; Danquah, M.K. Bioanalytical evaluation of Lactobacillus delbrueckii subsp. lactis 313 cell-envelope proteinase extraction. Chem. Eng. Sci. 2013, 95, 323-330.

14. Sadat-Mekmene, L.; Genay, M.; Atlan, D.; Lortal, S.; Gagnaire, V. Original features of cell-envelope proteinases of Lactobacillus helveticus: A review. Int. J. Food Microbiol. 2011, 146, 1-13. [CrossRef] [PubMed]

15. Stefanovic, E.; Kilcawley, K.N.; Rea, M.C.; Fitzgerald, G.F.; McAuliffe, O. Genetic, enzymatic and metabolite profiling of the Lactobacillus casei group reveals strain biodiversity and potential applications for flavour diversification. J. Appl. Microbiol. 2017, 122, 1245-1261. [CrossRef] [PubMed]

16. Zhang, S.; Zhang, L.; Zhang, L.; Feng, Z.; Shigwedha, N. Screening, purification, and characterization of proteinase from 3 Lactobacillus delbrueckii subsp. bulgaricus. RSC Adv. 2015, 5, 93733-93738. [CrossRef]

17. Gobbetti, M.; Smacchi, E.; Corsetti, A. The proteolytic system of Lactobacillus sanfrancisco CB1: purification and characterization of a proteinase, a dipeptidase, and an aminopeptidase. Appl. Environ. Microbiol. 1996, 62, 3220-3226. [PubMed]

18. Chen, H.; Ji, Z.; Shu, G.W.; Xing, H. Effect of probiotic Lactobacillus strains on Angiotensin-I Converting enzyme inhibitory activity from fermented goat milk. Adv. Mater. Res. 2012, 531, 442-445. [CrossRef]

19. Shu, G.W.; Yang, H.; Chen, H.; Zhang, Q.H.; Tian, Y. Effect of incubation time, inoculum size, temperature, pasteurization time, goat milk powder and whey powder on ACE-inhibitory activity in fermented milk by $L$. plantarum LP69. Acta Sci. Pol. Technol. Aliment. 2015, 14, 107-116. [PubMed]

20. Shu, G.W.; Huang, J.; Chen, L.; Lei, N.; Chen, H. Characterization of Goat Milk Hydrolyzed by Cell Envelope Proteinases from Lactobacillus plantarum LP69: Proteolytic System Optimization, Bioactivity, and Storage Stability Evaluation. Molecules 2018, 23, 1317. [CrossRef] [PubMed] 
21. Mehrnoush, A.; Mustafa, S.; Zaidul, I.S.M.D.; Mohd, Y.A.M. Optimization of the Conditions for Extraction of Serine Protease from Kesinai Plant (Streblus asper) Leaves Using Response Surface Methodology. Molecules 2011, 16, 9245-9260. [CrossRef] [PubMed]

22. Zhu, X.; Pan, D.D. Purification and Enzymatic Properties of Cell Envelope Protease from Lactobacillus fermentum. Food Sci. 2011, 32, 262-268.

23. Yamamoto, N.; Akino, A.; Takano, T. Purification and specificity of a cell wall-associated proteinase from Lactobacillus helveticus CP790. Int. J. Biochem. 1993, 114, 740-750. [CrossRef]

24. Fernandez de Palenzia, P.; Pelaez, C.; Martin-Hernandez, M.C. Purification and characterization of the cell wall proteinase of Lactobacillus casei subsp. casei IFPL731 isolated from raw goat's milk cheese. J. Agric. Food Chem. 1997, $45,3401-3405$.

25. Genov, N.; Filippi, B.; Dolashka, P.; Wilson, K.S.; Betzel, C. Stability of subtilisins and related proteinases (subtilases). Int. J. Pept. Protein Res. 1995, 45, 391-400. [CrossRef] [PubMed]

26. Rodríguez Patino, J.M.; Miňones Conde, J.; Linares, H.M.; Pedroche Jiménez, J.J.; Car-rera Sánchez, C.; Pizones, V.; Rodríguez, F.M. Interfacial and foamingproperties of enzyme-induced hydrolysis of sunflower protein isolate. Food Hydrocoll. 2007, 21, 782-793. [CrossRef]

27. Corrochano, A.R.; Buckin, V.K.; Phil, M.; Giblin, L. Invited review: Whey proteins as antioxidants and promoters of cellular antioxidant pathways. J. Dairy Sci. 2018, 101, 1-15. [CrossRef] [PubMed]

28. Ma, S.; Wang, C.N.; Guo, M.G. Changes in structure and antioxidant activity of $\beta$-lactoglobulin by ultrasound and enzymatic treatment. Ultrason. Sonochem. 2018, 43, 227-236. [CrossRef] [PubMed]

29. Rezvan, K.; Asghar, T.K.; Ahmad, M.; Reihane, K. Allergenicity reduction of bovine milk $\beta$-lactoglobulin by proteolytic activity of lactococcus lactis $\mathrm{BMC12C}$ and $\mathrm{BMC} 19 \mathrm{H}$ isolated from Iranian dairy products. Int. J. Biol. Macromol. 2018, 112, 876-881.

30. Kumar, D.; Chatli, M.K.; Singh, R.; Mehta, N.; Kumar, P. Antioxidant and antimicrobial activity of camel milk caseinhydrolysates and its fractions. Small Ruminant Res. 2016, 139, 20-25. [CrossRef]

31. Carter, D.; He, X.; Munson, S.; Twigg, P.; Gernert, K.; Broom, M.; Miller, T. Three-dimensional structure of human serum albumin. Science 1989, 244, 1195-1198. [CrossRef] [PubMed]

32. Agyei, D.; He, L.Z. Evaluation of cross-linked enzyme aggregates of lactobacillus cell-envelope proteinases, for protein degradation. Food Bioprod. Process. 2015, 94, 59-69. [CrossRef]

33. Bradford, M.M. A rapid and sensitive method for the quantitation of microgram quantities of protein utilizing the principle of protein-dye binding. Anal. Biochem. 1976, 72, 248-254. [CrossRef]

34. Ngo, L.T.A.; Pham, T.L.; Le, V.V.M. Purification of Endopolygalacturonase from submerged culture of Aspergillus awamori L1 using a two-step procedure: Enzyme precipitation and gel filtration. J. Food Res. Int. 2008, 15, 135-140.

35. Liu, Z.L.; Pan, J.H. A practical method for extending the biuret assay to protein determination of corn-based products. Food Chem. 2017, 224, 289-293. [CrossRef] [PubMed]

36. Lineweaver, H.; Burk, D. The determination of enzyme dissociation constants. J. Am. Chem. Soc. 1934, 56, 658-666. [CrossRef]

(C) 2018 by the authors. Licensee MDPI, Basel, Switzerland. This article is an open access article distributed under the terms and conditions of the Creative Commons Attribution (CC BY) license (http://creativecommons.org/licenses/by/4.0/). 